УДК 391(=512.145)

\title{
FOLK COSTUME TRADITIONS IN THE MODERN CULTURE OF THE VOLGA-URAL TATARS
}

\author{
S.V.Suslova \\ Marjani Institute of History of the Tatarstan Academy of Sciences \\ Kazan, Russian Federation \\ sv_suslova@mail.ru
}

The article is based on the materials of the Historical and Ethnografic Atlas of the Tatar People (volume "Folk Costume") prepared at the Institute of History of the Tatarstan Academy of Sciences. In the pre-national period of the Tatar's history there were many various local, ethno-confessional and other complexes of costume. Its formation was closely linked to the characteristic properties of the complex ethno-cultural history of the local groups of Tatars (the Kazan Tatars, the Mishar Tatars, and the Christian Tatars or Kryashens), as well as their religion (Islam, Christianity, Heathenism). In the late $19^{\text {th }}$ - early $20^{\text {th }}$ centuries, during the development of economic and cultural communications between Tatars of Russia's separate regions, the common national Tatar costume was formed. City traditions of the Kazan Tatars have lie at the core of its formation. These traditions were distinguished by the style of a costume tendency to change - from archaic monumental national forms to more refined, corresponding to directions of the all-European fashion of that time. The "secondary folklore forms" characterize the present stage of transformation of the Tatar national costume as a whole - the aspiration of professionals to use national traditions in professional culture (graphic, arts and crafts arts, theatre, scenic folklore, modern modeling, museum expositions as a symbol of reconstruction of ethnic identity). Several trends present folk costume traditions in the modern festive culture of the Volga-Ural Tatars: the ethnographic (authentic) Tatar costume; the folkloristic (neo-folklore) variation of traditional costume; the so-called symbolical national sign the avant-garde costume. As the element of the ethnic culture, the national costume is the most important related to the individual. It represents a symbolical sign-category, an original social-cultural code and transmits the ethnic information from the past to the future.

Keywords: Volga-Ural Tatars, local groups, national costume, handicrafts, folk traditions, transformation, reproduction

For citation: Suslova S.V. Folk Costume traditions in the modern culture of the Volga-Ural Tatars. Istoricheskaya etnologiya, 2021, vol. 6, no. 1, pp. 96-105. https://doi.org/10.22378/he.2021-6-1.96-105

The Tatars are Turkic speaking people in the Volga area of Russia. The formation of the ethnic culture of Tatars, including their national costumes, is related to the ethno-cultural traditions of large multiethnic state formations, such as the Volga Bulgaria, the Golden Horde, the Kazan Khanate, and the Russian empire at different historical periods. 
The traditional costumes of the Volga Tatars, especially the ones of the Kazan Tatars, went out of use early. That happened as the result of early urbanization of the Tatars and introduction to the European culture, including the European fashion. During the Soviet period, it was explained by the phenomenon of totalitarianism in the field of culture (the persecution to the national crafts, the scornful attitude to the female needlework, orientation on the proletarian culture, etc). By the end of the 20th century, the traditional Tatar costume - in all its ethnic-territorial, ethnic-confessional displays - had practically been lost and remained unknown to the Tatars. It led to mass-scale appearance of a simplified reproduction of costumes used in Tatarstan and especially, in the Tatar diasporas of Russia. As an ethnic culture element, the national costume is the most important item related to an individual. It represents a symbolical signcategory, an original social-cultural code which transmits ethnic information from the past to the future.

The problem of using the symbolical-sign forms of the traditional culture of Tatars has especially sharply raised in connection with activisation of the ethno-political processes in the context of the Post-soviet reorganization. It was one of the main reasons for serious study of the Tatar's folk culture by Tatarstan ethnologists. The basic research of the Tatar folk costume began in the 1970s and was finished and published in one of the volumes of the Historical and Ethnographic Atlas of the Tatar people in 2000. The publication included a lot of typological and mapped materials based on ethnological field works in the Volga area, in about 400 villages. We have studied all Tatar folk costume collections in almost all Russian museums and through archives, early graphic and written sources. This complex of sources comprises also authentic materials of the earlier periods of the Tatars' history (of the Kazan Khanate period, in particular). It can be explained by relative stability and continuity of the folk culture typological attributes.

\section{Traditional Tatar costumes. Local groups}

Our research has shown, that in the pre-national period of the Tatar's history (in the middle of the $19^{\text {th }}$ century and earlier) there were many various, local, ethno-confessional and other complexes of costume. Their formation was closely connected with the characteristic properties of the complex ethno-cultural history of the local groups of Tatars (the Kazan Tatars, the Mishar Tatars, and the Christian Tatars or Kryashens) and their religion as well (Islam, Christianity, and Heathenism).

The Kazan Tatars is the basic group in the Volga area. The city of Kazan and the so-called Zakazan'e region on the left bank of the Volga river, including the north part of Zelenodolsk district, almost all Arsk, and the western part of Sabinsk districts of Tatarstan. It represent the most orthodox features of the Kazan Tatars folk costumes which was mainly associated with the ethnic-cultural traditions of Turkic peoples of Eurasia. These districts represented the political, 
economical and cultural centres of the Tatar people. The Kazan Tatars resided here the most compactly. The methodological aspect is to consider the ways of the Kazan Tatars traditional costumes formation and to examine their town and rural variations which have independent lines of development.

\section{Kazan Tatars city costume}

Formation of the so-called Kazan Tatars city costume is based on the ethnic traditions of the Eastern Bulgar state in the Volga and Kama basin, the Golden Horde and the Kazan Khanate, which was remarkable for its advanced town culture. For instance, the typological similarity can be found in the Kazan Tatar women's cone shaped headdresses covered by the metal plates and beads. The area of distribution of these high headdresses limited by the city of Kazan and the Zakazan'e region, which was the territorial and ethnic centre of the Kazan Khanate. Medieval traditions can be noticed through the forms and techniques of traditional jewellery, ornaments, footwear etc.

Formation of the Kazan Tatar's city costume is closely linked to the traditions of Islam and the oriental Turkic-Islamic traditions, on the whole. This tradition is represented by the so-called lower hats: for men - the tubetei cap, dressed with a hat, cap or turban, for women a special cap, obligatory covered by the cap, veil or scarf. Islamic traditions were especially eloquently reflected in the jewellery. Some jewels had an aesthetic function and the role of a Muslim amulet ornamented by engraving in Arabian with the benevolent citations from the Koran.

\section{Kazan Tatars rural costumes}

The formation of the rural costume of the Kazan Tatars to a much greater degree (in comparison with the town's variety) is connected with the traditions of the Finno-Ugric peoples of the Volga region and to a lesser degree with Eastern Muslims (a rural aristocracy and clergy is an exception). In addition, it is not casual. The Finno-Ugric component was one of the basic in ethnic culture of the Volga Bulgars. During the history, in the period of the Kazan Khanate and later in Russia, the Kazan Tatars supported the cultural communications with the Finno-Ugric peoples. For instance, our research has shown that the so-called Zakazan'e region of the Kama area was the territory of the kalfak special headdress of the Kazan Tatar women where its manufacturing reached the level of mass production. Small kalfak with high hatband played a role of so-called, horn-shaped ornament in these geographic areas. The horn-shaped headdress was typically worn among Finno-Ugric peoples of the Volga area. It is a commonly known fact that a similar headgear of Mari women was churik. We could suppose that that small kalfak with high hatband was formed in the area of socalled Kazan region on the basis of horn-shaped headdresses of Finno-Ugrian people as part of close communication between the Kazan Tatars and the Maris and other peoples of the Volga area. This, probably, could be explained by the 
common features of women's ornaments of a rural costume of the Kazan Tatars and Finno-Ugric people (the Mordva, Mari, Udmurts) of the region. The closest analogue consists of functional affinity and identity of forms of the various types of ornaments, especially breast ornaments, made on textile basis covered with silver coins. The special Muslim hasite breast ornament was compiled, for example, of the use of boti, a security chapter from the Koran by the Eastern Islam tradition, and of the local breast ornament used as an amulet at FinnoUgric people. In parallel with hasite-amulet in a rural costume of the Kazan Tatars, as well as at the majority of Finno-Ugric peoples of the Volga region, occurred hasite-ornament without any Islam element, but with traces of Paganism. Probably, firstly the same hasite-ornament existed in the Kazan Tatars' culture, which was transformed to a specific Islam hasite-amulet later, under the influence of Eastern Islam traditions. Our studies show that the hasite-ornament was mainly spread at the periphery, in the rural areas, but the Islam hasite-amulet was present in the environment of cities related to the Islamic traditions more closely.

\section{Kryashen costumes}

The Christian Tatars or Kryashens is a confessional group of the Volga Tatars, living on the same territory with the Kazan Tatars, in Tatarstan. They were formed in the process of Christianization of the Turkic peoples of the Volga area in the $16-17^{\text {th }}$ centuries ("Old Christians") and in the first half of the $18^{\text {th }}$ century ("New Christians"). In contrast to the Kazan Tatar variations of costume which have distinguishable visible uniformity of elements making them, the Christian Tatar's costume complexes noticeably differed by their structuraltypological substance. At the origin of all local costume types of Kryashens, various early Turkic components, in particular, the Bulgarian ones are represented. For instance, rudimentary preservation in a complex of their headgear wide frontlet ornamented with silver coin imitate the early helmet-type headwear of the Turkic people. The turban, a special Kryashen women's headwear represents the Kipchak component of their folk costume. For that reason, we and the other researchers cataloguised common ethnic elements in the early rural costumes of the Kazan Tatars and Kryashens. These consist of various cuts of some clothes, such as "oske itekle kulmek" women's dress with wide ruffles. The early types of women's headwear, such as ak kalfak - the white knitted cap and the "coin complex" of the women jewellery, especially the large plastron covered with coins, can also be included.

The Kryashen folk costume traditions had many analogue elements with the Finno-Ugric world. Commonality can be noticed in headdresses, decorations of clothes, and women's jewellery covered with coins. It can be explained by their close ethnic-cultural contacts with the Volga Finn people, such as Maris, Udmurts and Mordva, and their ancestors who inhabited the Volga Bulgaria, the Kazan Khanate, later the Russian state and, possibly, by the early ethno-cultural contacts with the Finno-Ugric people of Siberia. Researchers state the fact of 
continual resettlements of the ancestors of the Khanti, Mansi and Samoieds from Siberia to the West side of Europe, including the area of eastern part of the Kama region, in the period of migration peoples until the $16^{\text {th }}$ century.

Kryashen costumes adopted some ethnic traditions of the Russian culture, which was conditioned upon Christianity. We can see these similarities in the traditional men's and women's headwear (the sureke women's headgear represented an analogy of soroka Russian's headgear), in cut of the borchatka cloak), in the embroidery (for example, the cross-stitch, gold embroidery, etc). The Kryashens did not adopt the Tatar national dress for the reason of Christianity.

\section{Costumes of the Mishars and Kasim Tatars}

Archaisms and the picture of ethno-cultural multiplicity were especially clearly reflected in the Tatar folk clothes of the Western region of Volga area, the Oka and Sura river basin, which constitutes the territory of the Mishars and Kasim Tatars. There were two local groups of Mishars in the Oka and Sura river basin - the southern and the northern. In the costumes of the southern group of Mishars and Kasim Tatars the earliest analogies were linked to the steppe traditions of the Turkic, Iranian and Kazakh cultures. They include the tastar headwear, a relic of the ancient turban headwear, and embroidery with golden threads.

The women's costume of the southern Mishars, in the Liambir region, included the kashpau headgear, which was ornamented with silver coins, similar to the ancient helmet of Turkic peoples. The geographical area of kashpau distribution including not only the Turkic, but also Finno-Ugric peoples, suggests that this headwear was related to the early Turkic cultures in the period of the Volga Bulgaria having influence on the Finno-Ugric cultures.

In the Oka and Sura river basin the decoration of young Mishar women's shirts had a symbolic meaning. The Southern Mishars embroidered using running stitch the plastron and the hem of shirt, while the Northern Mishars embroidered using application, a kind of patchwork technique. In the costume of the Northern Mishars includes elements of the national Tatar (Turkic) traditions and some related to the Finno-Ugric traditions, including the Khanti and Mansi in Siberia. They are, for example, the special embroidery of the tastar, bushkigech headdresses, and the application of the dzule kulmek (women shirts).

\section{From traditional costumes to the national costume}

The national Tatar costume appeared as a result of relations between divers Tatar groups in late $19^{\text {th }}$ and early $20^{\text {th }}$ centuries, as part of the growth of economic and cultural life. The city traditions of the Kazan Tatars lie in the basis of its formation. Moreover, it was for a reason. The Kazan Tatars were the main and the most consolidated group of Tatars. In the consequence of the social, economic and cultural development, like the urban culture, crafts, advanced 
scales of manufacture, trade and road network, the Kazan Tatars created highly artistic variations of the national costume, which was distinguished by refinement of forms and aesthetic design. There was a tendency to transform the Tatar costume from the archaic folk forms into a more refined form corresponding with styles of the Russian and European fashion of the time. It was the period of the development of new forces and democratic tendencies. In clothes the spirit of the times was expressed by a more daring creative approach to the traditions, making the process of losing the clothes local traits more active, consolidating them in the common national standard. However, the process of formation of the national costumes was realized with different intensity in various regions. As we had seen, the Kryashens didn't accept the national form of costume at all. In the cities, this process was more active. Under the influence of new directions, the traditional costume lost some archaic elements. A new, refined style of the Tatar Costume was formed. New pieces of clothing, a short close-fitting sleeveless jacket kysmaly kulmek, a small kalfak headdress, ichigi boots or shoes were adapted in the costume. In the men's wear, it included a slightly short shirt, a short kamzol jacket, trousers of the European pattern, a short kazakin cloak, a kelepush-tubetei cap made of black velvet and ichigi boots with kaush leather galoshes.

\section{Tatar fashion: national costumes at present}

In the second half of the $20^{\text {th }}$ century the Tatar costume transformed into a gala-dress or a dress for stage, or a dress of professional nature. The modern fashion of the Tatar traditional costume is established on the scientific and aesthetic reconstruction of the local types, using the materials of the Historical Ethnographic Atlas of the Tatar People. The scientific reconstructions was accomplished by the author (Suslova S.V) with participation of professional painters. The primary attention was given to careful reproduction of the design and fashion, ornamental motives, jewellery, patterned textiles, leatherwork, embroidery, and application.

On stage, Tatar folklore ensembles use some variations of the Tatar fashion following general Russian tendencies. Several trends present folk costume traditions in the Modern Festive Culture of the Volga-Ural Tatars:

The ethnographic (authentic) Tatar costume. In this case the folklore ensembles perform traditional songs and dances related to the local tradition. For example, this is the Kryashen folklore ensembles which still preserve the traditional costume or some its relics.

The so-called folkloristic costume, when the folklore ensembles use a secondary, folklore or neo-folklore variation of a traditional costume. It is a costume made on the basis of scientific reconstructions. Such neo-folklore costumes are used on choreographic stages of the Mishars and the Kazan Tatars. A series of costume reproductions based on our research have been made for the Republic of Tatarstan State Ensemble of Song and Dance (Kazan) and for the 
State Ensemble "Bulgar" (Naberezhnye Chelny). The same folkloristic variation includes the revived costume which is represented at museum expositions as a symbol of Tatar ethnicity.

The symbolical all-nation sign constume. This kind of costumes are made on authentic ethnographic basis. They are characterized by monumentality, large-scale of specific details, the traditional pattern, choice of textiles, and the traditional color scale. They are used on choral and choreographic stages of State ensembles and are associated with the traditions of the Kazan Tatars and the national Tatar costume as well.

The avant-garde costume. It is linked to developing stage costumes for avant-garde stages of the national theatre, opera and ballet performances and for a variety. This costume is similar to a symbolic sign using special ornament and colour.

Some symbolic pieces of the national costume are in use on national celebrations and festivals (secular holidays like the Day of the City, the Day of the Republic, or Islamic holidays Kurban Bayram, Uraza-Bayram) and on family festivities, weddings, and anniversaries. These include men's headgear similar to the kelepush-tubetei, the women's headgear kulfuks, the Tatar scarf, and jewels.

\section{Handicrafts}

A traditional dress is a result of various handicrafts and crafts which form its ensemble. Therefore, new variations of the national costume demand different kinds of national crafts and work of professional designers. Embroidery with golden threads, jewellery, and inlay work in leather play a significant role in the Tatar constume ensemble. The listed kinds of art were quite advanced and widely spread among the local groups of Tatars, though as a craft they gained momentum only among the Kazan Tatars.

The gold embroidery is the most ancient traditional kind of the Tatar national decorative applied art. The design of the Kazan Tatar's embroidery with silver and gold threads represents the most expressive and sophisticated component of decorations, such as as flower bouquets, golden feather 'altyn kauryj', and 'birds of happiness'. Gold embroidery was typically used in various types of headdresses, such as the Mishar salawych headdress, the sureke scarf of the Kryashen women, and the well-known kalfak headdress of the Kazan Tatars. It was customary to decorate plastrons, footwear, and accessories with embroidery.

The inlay-work in leather was a typical Tatar national decorative applied art. Women's chitek boots were usually made of the high-quality saffian dyed in bright color. Seams were sewed with silk or, sometimes, golden threads using a particular fine stitch concealing the junction of leather fragments (so-called seamless chitek boots). Inlay leather decoration certainly comprises the specificity of the Tatar footwear, manufacturing of which began in the Kazan Khanate period. 
The earliest kind of Tatar folk arts is jewellery, which was very popular. Silver was a commonly used material which was combined with such precious stones as carnelian, turquoise, emerald, etc. The gilded silver jewellery was the most common like the gold one. The Tatar silversmiths applied various techniques (chasing, filigree, engraving etc.) Benevolent inscriptions from the Koran written in Arabic script, which were linked to the Eastern Muslim traditions and a rich vegetative pattern, were used as a motive of engraving. The engraving was frequently accompanied by niello, or incrustation with a different kind of metal.

The incrustation of filigree cells with turquoise, carnelian was a very effective technique. Kazan was the center in the Volga region where filigree-work was highly advanced, and it had a specific nature. For example, In Russia filigree patterns were jointed with enamel. However, Tatar filigree was an exception. (Its scrolls give the graphic figures of the complicated fine patterns only.) According to the Russian scholars, the technique of the Tatar filigree was associated more with Central Asian or Grecian works rather than with the Russian variety. The Tatar jewellery came from the silversmith's tradition of the Volga Bulgaria, the Golden Horde, and the Kazan Khanate.

During the Soviet period the national Tatar decorative applied art was developing poorly. Golden thread embroidery, for example, practically disappeared. Craftesmen who had mastered the traditional skills of this type of embroidery became almost extinct in Tatarstan. There were only two traditional centers of gold embroidery on the territory of the former USSR: Torzhok, the famous school in Russia, and Bukhara (Uzbekistan). At present, a few designers, professional gold embroidery masters, they had undertaken training in the above-mentioned centres, are available in Kazan. They are well-familiarized with the Tatar tradition of golden thread embroidery and create unique decorations for costumes of folklore ensembles or for exclusive couture fashion collections. Besides, their works replenish museum and private collections of Tatarstan, including the well-known Turan foundation. The Turan foundation, which is a member of the European branch of the World Centre for Traditional Arts and Crafts, is the leading enterprise of the national decorative applied art and crafts in Tatarstan.

Professional stylists have a special role in the preservation of the national Tatar costume traditions. At present, this constitutes a difficult problem relating to the fashion dress and to the national costume. Fashion designers quite often follow the road of superficial stylisation, adding the decorative national motives mechanically into modern, europeanised clothing design. However, there have been examples of successful experiences, especially in the Kazan Fashion Houses. For instance, in the Fashing House Ildan successfully implements dresses the Tatar gold embroidery traditions in its exclusive and commercial fashion lines. The fur design house Melita effectively applies leather mosaic traditions. The silversmiths of the Almaz Holding company use the traditions of the national Tatar jewellery when working on elite jewellery collections. 
At the turn of the $20^{\text {th }}$ and $21^{\text {st }}$ centuries, during the Muslim Renaissance period, which influenced the ideological, social and cultural life of the Tatar society, young Tatar women adopted hijab veil from the Eastern Islamic tradition. The stream of Muslim clothes, which was brought from the Arabian world, for the most part is inconsistent with the secular traditions of the Volga region Tatars. Therefore, the market of modern Muslim clothing have been developing in Tatarstan over the last few years. Professional designers create collections of clothes for Tatar Muslim women taking into account international fashion trends and the ethnic specifics of a Tatar folk dress, according to the canons of Islam. It is necessary to point out that the traditional pattern, the silhouette of a Tatar folk costume in a straight A-shaped line, is not in conflict with the strict requirements of Shariat. This trend is quite recent, but it attracted attention of Muslims not only in Tatarstan, but also in Russia.

The symbolical function of a traditional Tatar costume remains sustained. The present stage of the national costume transformation is generally characterized by the presence of "secondary" (neo-folklore) variations and by designers's attempts to introduce national folk traditions into the modern fashion. As an ethnic symbol, the Tatar national costume traditions are implemented in the local variations of culture (as a stage costume). It results from insufficient completeness of ethnic processes among separate groups of the Volga region Tatars. On the other hand, the traditions of the Tatar national costume are also used in the generalized national form due to consolidation of the all-Tatar selfidentity. In spite of dynamism of the social processes and their unification, the national costume continues to act as an actual intermediary between the types of cultures of the various chronological periods of ethno-cultural history of peoples, "carrying out the communication, translation, and adoption of certain, significant information for the given type of culture".

\section{REFERENCES}

Suslova S.V., Mukhamedova R.G. Narodnyy kostyum tatar Povolzh'ya i Urala (seredina XIX - nachalo XX vv.). Istoriko-etnograficheskiy atlas tatarskogo naroda [Folk costume of the Tatars of the Volga region and the Urals (mid-19th - early 20th centuries). Historical and ethnographic atlas of the Tatar people]. Kazan, 2000. (in Russian)

About the author: Svetlana V. Suslova, Cand. Sc. (History), Leading Research Fellow of the Department of Ethnological Research, Marjani Institute of History of the Tatarstan Academy of Sciences (7A Baturin St., Kazan 420111, Russian Federation); sv_suslova@mail.ru 
Suslova S.V. Folk costume traditions in the modern culture of the Volga-Ural Tatars

\section{ТРАДИЦИИ НАРОДНОГО КОСТЮМА В СОВРЕМЕННОЙ КУЛЬТУРЕ ВОЛГО-УРАЛЬСКИХ ТАТАР}

\section{С.В. Суслова}

Институт истории им. Ш. Марджани Академии наук Республики Татарстан Казань, Российская Федерация

sv_suslova@mail.ru

Публикация подготовлена на основе материалов Историко-этнографического атласа татарского народа (том «Народный костюм»). В условиях современной глобализации, несмотря на унификацию социокультурных процессов и усиление роли общечеловеческих ценностей, наблюдается тенденция к сохранению и возрождению утраченных форм традиционного татарского костюма. Ориентация на воспроизводство этнических стереотипов наблюдаются в различных, в основном «вторичных» формах культуры (костюм-новодел, костюм-реконструкция, дизайнерские разработки). В качестве этнического символа они используются в локальных вариантах культуры, что связано с недостаточной завершенностью этнических процессов у отдельных этнографических групп народа (татармишарей, кряшен) и в обобщенном виде, что обусловлено усилением в постсоветский период «общетатарского» самосознания. Воспроизводство этнических традиций в современном татарском костюме в целом соответствует общероссийским и европейским тенденциям. Оно идет по нескольким направлениям: этнографическое, фольклористическое, общенационально-знаковое, авангардное, ритуальнообрядовое и профессиональное моделирование.

Ключевые слова: волго-уральские татары, локальные группы, народный костюм художественные ремесла, народные традиции, воспроизводство

Для цитирования: Suslova S.V. Folk Costume traditions in the modern culture of the Volga-Ural Tatars // Историческая этнология. 2021. Т. 6, №1. С. 96-105. https://doi.org/10.22378/he.2021-6-1.96-105

Сведения об авторе: Суслова Светлана Владимировна - кандидат исторических наук, ведущий научный сотрудник, отдел этнологических исследований Института истории им. Ш. Марджани Академии наук Республики Татарстан (420111, ул. Батурина, 7А, Казань, Российская Федерация); sv_suslova@mail.ru 